\title{
Comparative deformability of compressive members reinforced with steel and GFRP reinforcement
}

\author{
Andrey Lapshinov* and Pavel Deminov \\ Moscow State University of Civil Engineering, Yaroslavskoe shosse, 26, Moscow 129337, Russia
}

\begin{abstract}
The paper contains the results of testing of compressive members reinforced longitudinally and transversally with steel and GFRP reinforcement. The spacing of transverse reinforcement (stirrups) and longitudinal reinforcement ratio varied in the specimens. The stress-strain, stress-Poisson's ration, stress-volumetric strain relationships for tested specimens are given. It was observed that the appearance of cracks occurred with loading $90 \%$ of total. By the results of testing investigated that with the decreasing of spacing of transverse reinforcement the strength of specimens increased. Conclusion is made that by using small spacing of transverse reinforcement transverse strains and Poisson's ratio decreasing, while modulus of elasticity increasing.
\end{abstract}

\section{Introduction}

Despite the release in Russia of GOST for fiber-reinforced polymer (FRP) reinforcement with the compression test method [5] and the official design codes for structures with FRP reinforcement (Appendix L to SP 63.13330.2012 and SP 295.1325800.2017) [6,7] the question of design compressed elements still remains open. According to Appendix L, the design compression strength of FRP reinforcement in calculations should be assumed to be zero. However, as shown in studies $[9,10]$, composite reinforcement can be effectively used in centrally compressed elements. As it was presented in articles $[9,10,12]$ and design codes $[8,11]$ for today there is a need for further research of FRP reinforcement in compressed elements. In fact, the behavior of FRP reinforcement in reinforced concrete structures is being studied $[1,3]$. Some studies have shown the prospect of use FRP reinforcement in compressed concrete reinforced elements with frequent spacing of transverse reinforcement. In addition, there are some real examples of implementing FRP reinforcement into compressed reinforced concrete structures of mass application can be observed [2]. Withal some other studies are underway to optimization the design of traditional compressed elements under different load combinations.

\footnotetext{
* Corresponding author: La686@yandex.ru
} 


\section{Methods}

To obtain the influence of longitudinal and transverse FRP reinforcement on the strength and deformability of compressed concrete elements, the columns reinforced longitudinally and transversally with glass fibre-reinforced (FRP) and steel reinforcement were tested for axial compression. In accordance with the research program, concrete prisms of $200 \times 200 \times 600 \mathrm{~mm}$ square section made of heavy concrete with a cubic strength of 26.3 $\mathrm{N} / \mathrm{mm} 2$ were designed as prototypes.

During the tests the influence of the following parameters were investigated:

- Spacing of transverse reinforcement (stirrups);

- the type of longitudinal reinforcement (GFRP, steel);

- longitudinal reinforcement ratio.

All specimens were reinforced longitudinally by GFRP ribbed rebars $\varnothing 12$ or $6 \mathrm{~mm}$ («Armastek» brand), or steel reinforcement of A500 grade. For installation in the design position, a tying wire connected all the bars in the reinforcement cages. For steel-reinforced specimens transverse reinforcement was in the form of bent square shaped stirrups made of plain steel rebars grade A240, enveloping longitudinal reinforcement. For FRP-reinforced specimens GFRP stirrups («Galen» brand) with a diameter of $6 \mathrm{~mm}$ were used. The spacing of the stirrups varied from 50 to $100 \mathrm{~mm}$. With a reduced spacing of the stirrups, an confinement reinforcement effect was created, which has a positive effect on increasing the load-carrying capacity of compressed concrete $[9,10]$. Reinforcement layouts of the specimens are shown in Fig. 1. The characteristics of the specimens are shown in Table 2.

In order to obtain the physical-mechanical characteristics of the reinforcement, tests were carried out in accordance with GOST 31938-2012 [5] for GFRP reinforcement and in accordance with GOST 12004 for steel reinforcement. The results of the tests are shown in Table 1. From the analysis of the test results, it can be concluded that the GFRP reinforcement has a higher value of the ultimate stress, does not have a yielding point, and the behaviour is linear up to failure. At the same time, the modulus of Elasticity of GFRP reinforcement is lower than that of the steel reinforcement by 3 times for the tensile and almost 7 times the compression.

Table 1. Comparative physic-mechanical characteristics of reinforcement, used for specimens: steel grade A240, A500 and GFRP reinforcement.

\begin{tabular}{|l|l|l|l|l|l|}
\hline \multirow{2}{*}{$\mathrm{N}$} & \multicolumn{1}{|c|}{ Parameter } & \multicolumn{4}{|c|}{ Type and diameter of reinforcement } \\
\cline { 3 - 6 } & & $\begin{array}{l}\text { A240 steel } \\
\text { A12 steel } \\
\text { A500 }\end{array}$ & $\begin{array}{l}\text { Ø6 } \\
\text { GFRP }\end{array}$ & $\begin{array}{l}\text { Ø12 } \\
\text { GFRP }\end{array}$ \\
\hline 1 & Effective diameter, mm & 6 & 12 & 5,6 & 11,6 \\
\hline 2 & Factual cross section area, $\mathrm{mm}^{2}$ & 28,3 & 113 & 24,7 & 106 \\
\hline 3 & Ultimate tensile strength, MPa & 501 & 679 & 1110 & 1106 \\
\hline 4 & Yielding strength, MPa & 376 & 598 & - & - \\
\hline 5 & Elongation, \% & 16 & 9,7 & 2,41 & 2,36 \\
\hline 6 & Tensile Modulus of Elasticity, GPa & 199 & 200 & 58123 & 54191 \\
\hline 7 & Ultimate compressive strength, MPa & 240 & 679 & 350 & 600 \\
\hline 8 & Compressive modulus of Elasticity, GPa & 200 & 200 & 30 & 30 \\
\hline
\end{tabular}




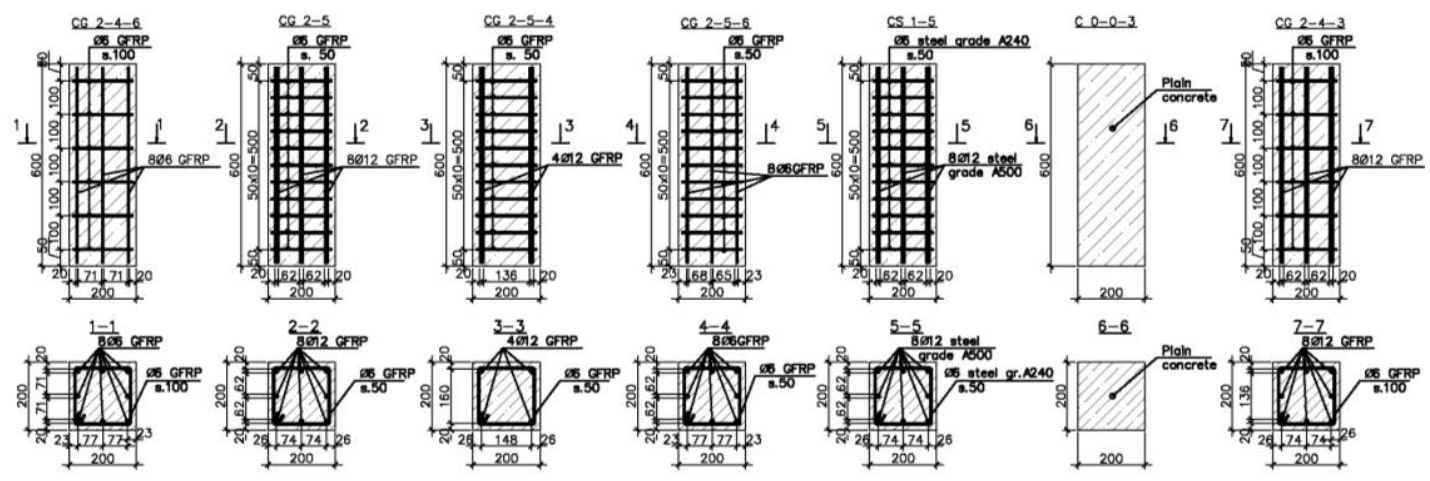

Fig. 1. Reinforcement layout of testing specimen.

\section{Results and discussions}

To conduct a comprehensive analysis of the behavior of the test specimens under load, stress-strain $(\sigma-\varepsilon)$ and volumetric strain $(\Delta Q)$ were plotted.

Volumetric strain can be calculated in following equation:

$$
\Delta Q=\varepsilon_{n p}-2 \varepsilon_{n o n}
$$

Table 2. Specification of specimens.

\begin{tabular}{|c|c|c|c|c|c|c|c|}
\hline \multirow[t]{2}{*}{$\mathrm{N}$} & \multirow[b]{2}{*}{ 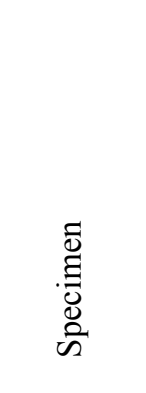 } & \multirow{2}{*}{ 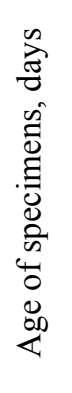 } & \multicolumn{2}{|c|}{$\begin{array}{l}\text { Longitudinal } \\
\text { reinforcement }\end{array}$} & \multicolumn{2}{|c|}{$\begin{array}{c}\text { Transverse } \\
\text { reinforcement }\end{array}$} & \multirow[b]{2}{*}{ 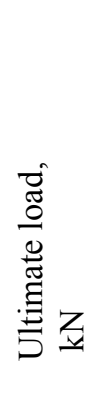 } \\
\hline & & & 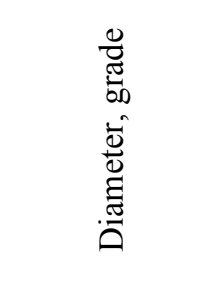 & 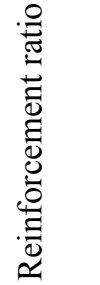 & 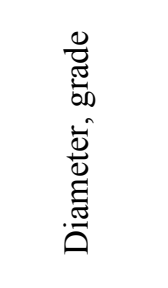 & 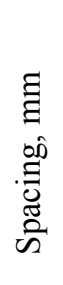 & \\
\hline 1 & C 0-0-3 & 489 & - & - & - & & 849,6 \\
\hline 2 & CG 2-4-6 & 480 & $8 \varnothing 6$ GFRP & 0,566 & Ø6 GFRP & 100 & 901,3 \\
\hline 3 & CG 2-4 & 465 & $8 Ø 12$ GFRP & 2,26 & Ø6 GFRP & 100 & 901,3 \\
\hline 4 & CS 1-5 & 386 & $8 \varnothing 12$ A500 & 2,26 & Ø6 A240 & 50 & 1140 \\
\hline 5 & CG 2-5 & 514 & 8Ø12 GFRP & 2,26 & Ø6 GFRP & 50 & 993,6 \\
\hline 6 & CG 2-5-4 & 391 & $4 \varnothing 12$ GFRP & 1,13 & Ø6 GFRP & 50 & 901,3 \\
\hline 7 & CG 2-5-6 & 458 & $8 Ø 6$ GFRP & 0,566 & Ø6 GFRP & 50 & 936,5 \\
\hline
\end{tabular}

Annotation: First letter means the type of specimen («C»-Column); second letter type of reinforcement («S» - steel reinforcement; «G» - glass fiber-reinforced polymer reinforcement;). The first number defines type of stirrups («1»- steel stirrups $Ø 6 \mathrm{~mm}$ grade A240; «2» - GFRP stirrups Ø6 mm); second number - spacing of stirrups («4» - $100 \mathrm{~mm}$; «5»- $50 \mathrm{~mm}$ ). The number after letter means the diameter or quantity of longitudinal reinforcement: «4» - 4 rebars instead of 8 ; «6» - diameter of longitudinal reinforcement 6 $\mathrm{mm}$ instead of $12 \mathrm{~mm}$.

At the initial stages of loading, the behaviour of the specimens is similar and the differences are insignificant. 
However, with an increase in the load level and, accordingly, the stresses in the reinforced specimens, the stirrups restrain the transverse deformations, thereby increasing the longitudinal ones. It is logical that the more often the spacing of the stirrups, the greater the limitation of transverse deformations and the greater the increase in longitudinal deformations.

It can be noted that in a control specimen made of plain concrete without any reinforcement before failure at the same stresses, the transverse deformations are more than 3 times higher than for a specimen with steel reinforcement and 1.5...2.5 times higher than for specimens with GFRP reinforcement.

The upper edge of the crack formation was determined from the change in the volumetric strain curve $\Delta \mathrm{Q}$ (Fig. 2). It is obvious that in specimens with steel reinforcement the upper limit of cracking is shifted upwards in comparison to a control specimen of plain concrete without reinforcement. In specimens with GFRP reinforcement, due to the low modulus of elasticity of the FRP rods, the upper crack boundary is located lower than that of the sample with steel reinforcement and slightly higher than in the control specimen without reinforcement.

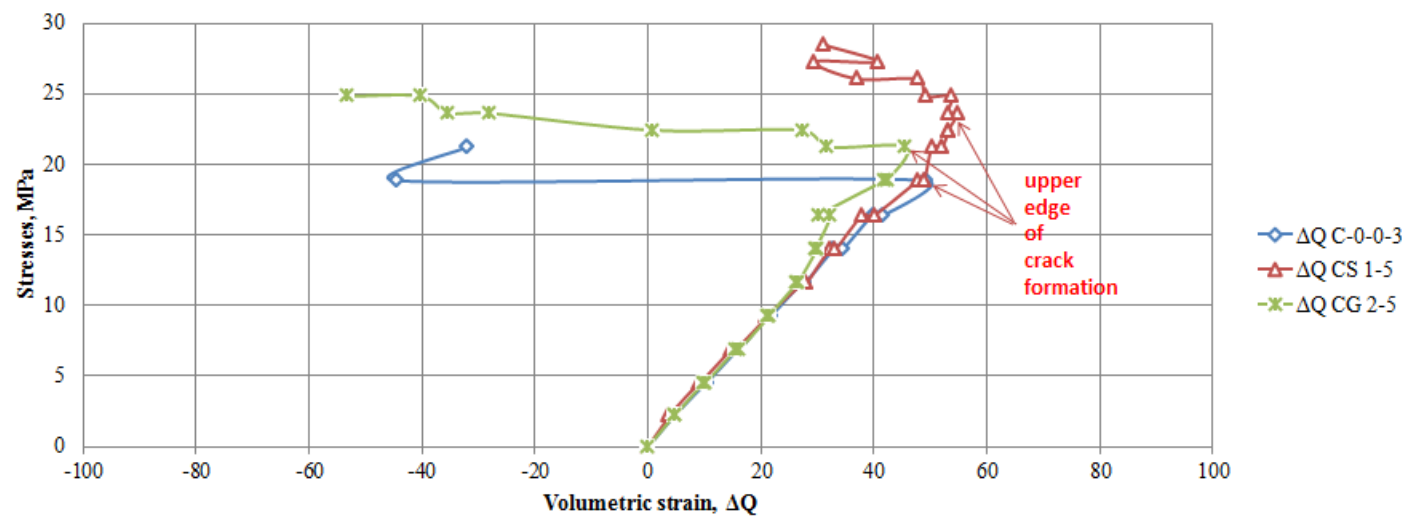

Fig. 2. Stress-volumetric strain relationship of specimens CS 1-5, C 0-0-3, CG 2-5.

Also, one of the aspect of the behaviour of specimens under load is the later formation of large values of rapid (inelastic) longitudinal strains when exposed to specimens reinforced with steel reinforcement in comparison with samples of plain concrete (without reinforcement) and reinforced with GFRP reinforcement. This fact can be explained by a much lower modulus of elasticity of GFRP reinforcement (4 times lower by tensile and 7 times lower by compression) compared to steel reinforcement. The ultimate strain of compressed concrete is associated with the process of redistribution of forces from concrete to elastically working reinforcement (as a result of appearance of inelastic deformations in concrete), which leads to a reduction in stresses in the concrete. The degree of redistribution of forces mainly depends on the amount of longitudinal GFRP reinforcement (percentage of reinforcement) and the stressed state of concrete in the section of the element, as well as the modulus of elasticity of longitudinal reinforcement.

After the formation of cracks, the growth of inelastic (plastic) strains becomes more intense, which is due to the loosening (decompression) of the concrete structure.

Specimens with steel and GFRP reinforcement showed similar initial behaviour. The behaviour of reinforced specimens can be attributed to a relatively plastic and more complex than that of a specimen without reinforcement. During the tests, vertical hair cracks began to appear at the loading level of $85-95 \%$ of the destructive load. Prior to this, no cracks were observed on the surface of the samples. Vertical cracks gradually increased in length and width with increasing load to destroy. At the stage preceding the destruction 
of concrete $(0,8-0,9 \mathrm{R})$, microcracks are combined into macrocracks, which is accompanied by the appearance of cracks in the sample that are noticeable to the eye. It is interesting to note that samples with a more frequent step of transverse reinforcement (stirrups) had smaller external fractures compared to specimens with a rare setting of transverse reinforcement (Fig. 5).

\subsection{The influence of reinforcement to strength and deformability of specimens}

\subsubsection{Type of reinforcement}

The influence of the type of longitudinal reinforcement (steel, GFRP) was evaluated on specimens with identical reinforcement with a spacing of transverse reinforcement $-50 \mathrm{~mm}$ (CS 1-5, CG 1-5) (Figure 3). Samples reinforced with GFRP reinforcement with a $50 \mathrm{~mm}$ spacing of transverse reinforcement showed behaviour similar to those with steel reinforcement with the same spacing of stirrups.

The use of GFRP and steel reinforcement increased the ultimate load by 1.17 and 1.34 times, respectively.

The effect of using composite reinforcement instead of steel can be considered insignificant. The load-bearing capacity of a specimen reinforced with GFRP reinforcement (for $\mu=2.26 \%, \mathrm{~s}=50 \mathrm{~mm}$ ) is only $13 \%$ lower than for a reinforcement-like specimen with steel reinforcement.

It can also be noted that samples with steel reinforcement showed greater ductility before failure compared to a similar specimen with GFRP reinforcement.

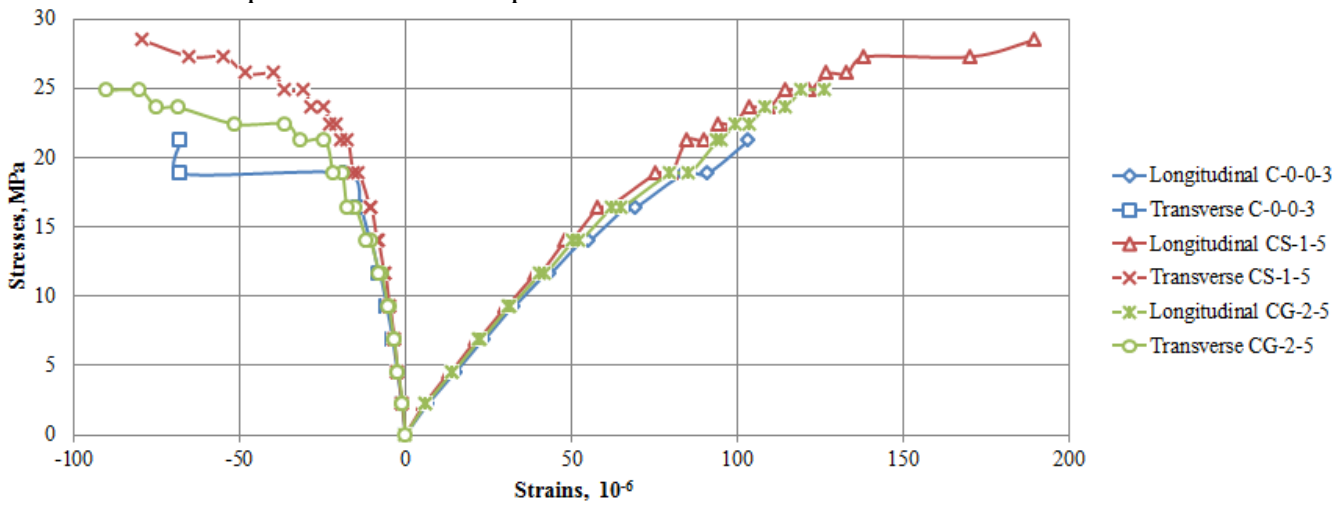

Fig. 3. Stress-strain relationship of specimens CS 1-5, CG 2-5, C 0-0-3.

\subsubsection{Spacing of stirrups}

The influence of the spacing of transverse reinforcement was evaluated on specimens with the same longitudinal reinforcement ratio and different spacing of the stirrups. In Fig. 4 are diagrams of the strength of the specimens versus the spacing of the transverse reinforcement. Their analysis shows that with a decrease in the spacing of stirrups and, accordingly, with an increase in the confinement effect of the inner concrete core, the limiting strains of concrete also increase. Compared with the control sample of pure concrete without reinforcement, the maximum longitudinal deformations are 2 times greater in samples with frequent setting of transverse reinforcement $(50 \mathrm{~mm})$. 


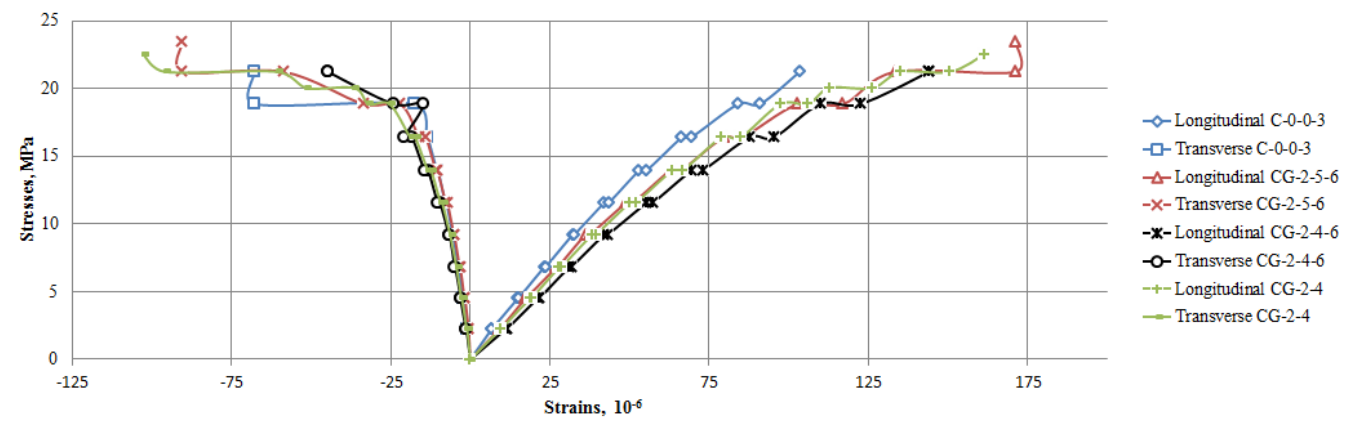

Fig. 4. Stress-strain relationship of specimens CG 2-4-6, CG 2-5-6, C 0-0-3, CG 2-4.

\subsubsection{Longitudinal reinforcement ratio}

Fig. 5 shows stress-strain diagrams of specimens designed with a spacing of stirrups 50 mm (CG 2-5-6, CG 2-5-4, CS 2-5) with three different longitudinal reinforcement ratios $(0,565,1,13$ and $2,26 \%$ respectively). It can be noted that low values of the longitudinal reinforcement ratio practically do not give an increase in the strength of the specimens; however, such specimens have a greater ductility before failure than in the case of a concrete specimen without reinforcement.

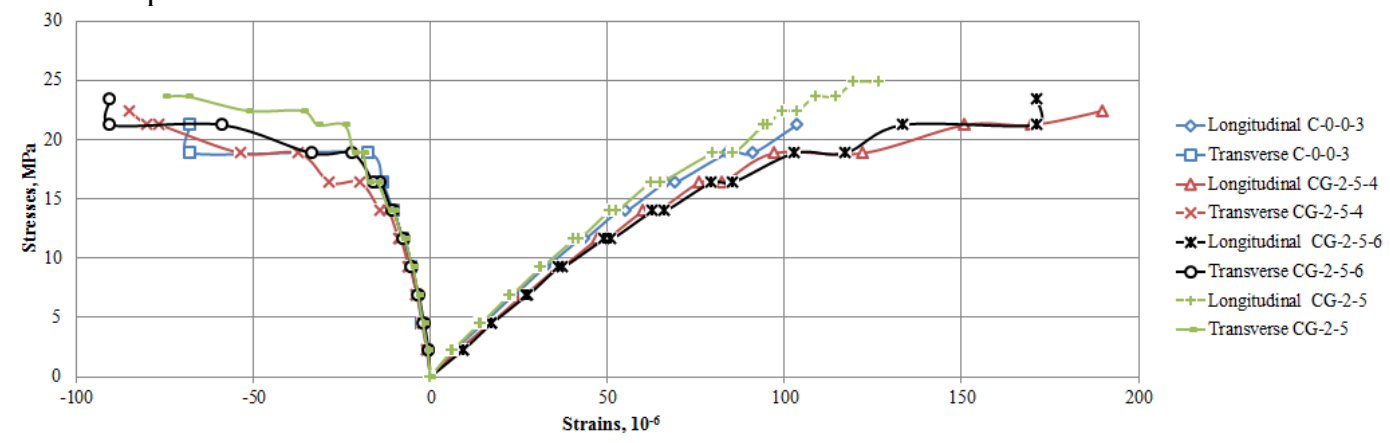

Fig. 5. Stress-strain relationship of specimens CG 2-5-4, CG 2-5-6, CG 2-5, C 0-0-3

\section{Conclusions}

1. The tested specimens, reinforced with steel and FRP reinforcement, show similar behavior under load. In samples with reinforcement of GFRP reinforcement with frequent spacing of transverse reinforcement, a plastic behavior (ductility) is observed before failure, as in samples with steel reinforcement.

2. The use of GFRP reinforcement with reduced spacing (both longitudinal and transverse) makes possible to achieve a significant increase in longitudinal deformation with decreasing transverse deformations compared to a control specimen without reinforcement.

3. The use of GFRP with frequent spacing of transverse reinforcement reduces the Poisson's ratio of reinforced specimens in comparison with control concrete specimen without reinforcement, i.e. reduces transverse deformations with increasing longitudinal.

4. The modulus of elasticity of specimens reinforced with a frequent step of the transverse reinforcement with a glass composite reinforcement is higher than for samples with a smaller step of transverse reinforcement and a sample without reinforcement. 
5. In specimens with a small spacing of transverse reinforcement, the upper cracking limit is shifted upward relative to the control specimen without reinforcement, i.e. cracks are formed later.

\section{References}

1. Lapshinov A.E. Issledovanie raboty SPA i BPA na szhatie // Vestnik MGSU. 2014. № 1. S. $52-57$.

2. Nikolaev V.N. Primenenie kompozitnoj polimernoj armatury dlya opor kontaktnoj seti s ankernym krepleniem na fundamentah / Nikolaev V.N., Stepanova V.F. // Promyshlennoe i grazhdanskoe stroitel'stvo. 2016. № 7. S. 79-84.

3. Plevkov V.S. K opredeleniyu raschetnyh napryazhenij v stal'noj i uglekompozitnoj armature normal'nyh sechenij zhelezobetonnyh ehlementov / Plevkov V.S., Baldin I.V., Nevskij A.V. // Vestnik Tomskogo gosudarstvennogo arhitekturno-stroitel'nogo universiteta. 2017. № 1 (60). S. 96-113.

4. Tamrazyan A.G. K raschetu izgibaemyh zhelezobetonnyh ehlementov s kosvennym armirovaniem szhatoj zony / Tamrazyan A.G., Manaenkov I.K. // Promyshlennoe i grazhdanskoe stroitel'stvo. 2016. № 7. S. 41-44.

5. GOST 31938-2012. Armatura kompozitnaya polimernaya dlya armirovaniya betonnyh konstrukcij. Obshchie tekhnicheskie usloviya.

6. SP 63.13330.2012. Aktualizirovannaya redakciya SNiP 52-01-2003. (s Izm. №1,2).

7. SP 295.1325800.2017 Konstrukcii betonnye, armirovannye polimernoj kompozitnoj armaturoj. Pravila proektirovaniya.

8. American Concrete Institute (ACI) Committee 440, [2015]. Guide for the Design and Construction of Concrete Reinforced with FRP Bars, ACI 440.1R-15, Farmington Hills, Mich.

9. Afifi, M. Z., Mohamed, H., and Benmokrane, B., [2013a]. - Axial Capacity of Circular Concrete Columns Reinforced with GFRP Bars and Spirals.l Journal of Composites for Construction.

10. Afifi, M. Z., Mohamed, H., and Benmokrane, B. [2014] Performance Evaluation of Concrete Columns Reinforced Longitudinally with FRP Bars and Confined with FRP Hoops and Spirals under Axial Load. Journal of Bridge Engineering.

11. Canadian Standards Association (CSA), [2012]. Design and Construction of Building Components with Fiber Reinforced Polymers, CAN/CSAS806-12, Rexdale, Toronto.

12.Zadeh, H.J., Nanni, A., [2013] Design of RC Columns Using Glass FRP Reinforcement. Journal of Composites for Construction

13. Tamrazyan A., Avetisyan L. COMPARATIVE ANALYSIS OF ANALYTICAL AND EXPERIMENTAL RESULTS OF THE STRENGTH OF COMPRESSED REINFORCED CONCRETE COLUMNS UNDER SPECIAL COMBINATIONS OF LOADS. In proceedings: MATEC Web of Conferences 5. Ser. "5th International Scientific Conference "Integration, Partnership and Innovation in Construction Science and Education", IPICSE 2016" 2016. C. 01029.

14. Tamrazyan A.G., Avetisyan L.A. EXPERIMENTAL AND THEORETICAL STUDY OF REINFORCED CONCRETE ELEMENTS UNDER DIFFERENT CHARACTERISTICS OF LOADING AT HIGH TEMPERATURES. Procedia Engineering (see in books). 2016. T. 153. p. 721-725. 